\title{
SCIENCE AND DEFENCE IN GREAT BRITAIN
}

$\mathrm{T}$ HE statement made by the Prime Minister, Sir Anthony Eden, in the House of Commons on October 25, on the administrative responsibilities of the Minister of Defence made no specific reference to the position of the Defence Research Policy Committee. Sir Anthony stated that arrangements have been made to co-ordinate, under the Minister of Defence, planning and training for the joint action of civil and military forces in home defence. The Minister of Supply has become a fourth Defence Department within the co-ordinating powers of the Ministry of Defence, and the Minister is now responsible for seeing that the composition and balance of forces within individual Armed Services meet the strategic policy laid down by the Defence Committee. A new post of chairman of the Chiefs of Staff Committee, to which Sir William Dickson has been appointed, has been created, and this officer will normally be the United Kingdom representative on the Military Committee of the North Atlantic Treaty Organization and on other international defence organizations.

These arrangements were discussed in a debate on the Armed Services in the House of Lords on Novem. ber 8 and 9 , in which the importance of research and of the scientist in defence was repeatedly stressed. In reply to Lord Swinton, who had urged that the Minister of Defence should also be responsible for deciding what research programmes should be undertaken and their priority, the Lord President of the Council, Lord Salisbury, said that the Minister of Defence has already been given responsibility for framing general policy governing research and development. Lord Rea suggested that the immensely accelerating rate of scientific discovery imposes on the Government a great responsibility to assess the future in terms which no individual past training and no previous experience can fulfil. Lord Hore-Belisha, too, was concerned as to the extent to which the scientist exerts an effective influence on policy, and Lord Freyberg also urged that a forecast of the effect of scientific invention upon the conduct of future wars should precede any reorganization or amalgamation of the Services. No one outside those responsible for the conduct of research knows either the aim of scientific invention or what has already been accomplished. Lord Balfour, in particular, emphasized the need for scientifically trained personnel in the Services, and doubts were freely expressed as to the extent to which amalgamation is possible and the level at which integration is desirable.

The Parliamentary Secretary to the Ministry of Defence, Lord Carrington, replying to the debate, assured the House that the Government attaches the greatest importance to scientists playing a sufficient part in the central organization for defence. The chairman of the Defence Research Policy Committee attends meetings of the Chiefs of Staff Committeo whenever he wishes, and Lord Carrington doubted whether a week passes without him discussing some matters personally with the Chiefs of Staff. Although he is not a nember of the Defence Committee, his views are invariably known to, and expressed by, the Minister of Defence, and the Defence Committee on occasion invites him to attend. The Chiefs of Staff have also asked the Scientific Adviser to the Minister of Defence to be the chairman of subcommittees to consider long-term problems. Lord Carrington emphasized that there is always a strong representation of scientists at the major exercises held by the Service Departments and the North Atlantic Treaty Organization; scientists are encouraged to put forward their ideas, and they are warmly welcomed by members of all three Armed Services.

\section{THE BRITISH FLORA DURING 1955}

CTUDY of the British flora during 1955 has led $S$ to no outstanding additions to the list; but collectively the results represent important progress. This includes interesting extensions of the known range of some of the less-common species, a clearer understanding of the taxonomic value of various units, and the recognition of new ones. These, and other aspects, were illustrated by the exhibits at the annual exhibition meeting of the Botanical Society of the British Isles, arranged in the lecture room of the British Museum (Natural History) on November 28.

The meeting was attended by some three hundred members and guests, and a full account of the exhibits will appear in the Proceedings of the Society.

During the year many field botanists have been concentrating on work in connexion with the Distribution Maps Scheme ${ }^{1}$ organized by the Society. The direct results of this were shown in an exhibit prepared by the Cambridge headquarters of the Scheme, which included a map showing the 10.km. squares of the National Grid for which lists of more than 50, 150 and 250 species, respectively, have been received. Although considerable gaps still remain, the progress of the work, which is still only in its second year, is well up to expectations. Mr. F. Perring and Dr. S. M. Walters (Cambridge) also showed examples of distribution-patterns revealed in the course of local surveys for the Scheme around Newton Stewart (Galloway) and Llanrhaiadr (Denbigh and Montgomery).

A by-product of the Scheme was the discovery of Orchis militaris in Suffolk, where a colony of more than five hundred plants was found by a worker listing the species of a $10-\mathrm{km}$. grid-square. This very rare plant, of which photographs were shown, is new to East Anglia. As in the only other known British colony (in Buckinghamshire), a large number of flower heads were found eaten off; but some seed capsules mature. An equally important, and perhaps more surprising, extension of range was the discovery of Trientalis europaea in a boggy alder-birch coppice, also in Suffolk. This was shown by Dr. F. Rose (Bedford College, London), with a map of the 
distribution of the species in Britain showing that the new locality is some hundred and fifty miles south of the nearest previously known station for this northern plant.

The flora of Rockall, which is about three hundred miles off the north-west coast of Scotland, was the subject of an exhibit by Miss Y. Chamberlain (British Museum (Natural History)). As a result of collections made from near the base of the rock by Charcot in 1921, and from the upper parts by James Fisher on September 18 last, twenty-one plant species are now known. These include one lichen (Verrucaria sp.), the remainder being algae. No flowering plants are to be found on this sea-swept and isolated rock.

Miss M. E. Bradshaw (Durham College) showed large-scale distribution maps of some Alchemilla microspecies in Teesdale and other valleys. These were plotted on a grid of $0.2 \mathrm{~km}$. and showed interesting correlation with roadsides and fields used by grazing animals. A. C. Jermy (University College, Leicester) illustrated the distribution of Luronium natans. This was recorded from Ellesmere, in Shropshire, early in the nineteenth century and spread from Blake's Mere to the Shropshire Union Canal. It is still spreading in the Manchester, Stafford and Montgomery areas along the canals. Other localities are lakes, some of which are isolated in mountain districts, and it is suggested that waterbirds as well as water-carriage may be agents in its dispersal. Another aquatic was shown by Miss E. J. Gibbons and J. E. Lousley, who exhibited Alisma gramineum. This is already known from a lake in Worcestershire where it grows in shallow water with flowers, fruits and leaves usually above the surface. In September, Miss Gibbons discovered the species near Spalding in Lincolnshire, and subsequent investigation showed that it occurs in four rivers and drains. The plant there is completely submergedeven the fruits being well below the surface of the water-and very different superficially from the Worcestershire form. The occurrence of the species in Lincolnshire fits in well with the known Continental distribution and establishes it as an undoubted native in Britain.

Dr. C. D. Pigott (Sheffield) illustrated the distribution of the native race of Polemonium coeruleum on black humus-rich soils on ledges of limestone cliffs or screes in the Pennines and Cheviots. Transplant experiments suggest that the moisture content of the soil is critical. Its presence in widespread localities during late-glacial times has been confirmed repeatedly, and it is now known to have persisted through the post-glacigl. Dr. E. M. Evans (Nature Conservancy) provided an exhibit on the distribution and ecology of Primula farinosa. It is found in short turf grassland of dry soils, in parvocaricetum of flushed soils, and in fen, and its tolerance of this wide range of habitats can be explained by the theory that a high water-table is required for maximum development. An interesting study of the changes which have taken place in the flora of a small area in the course of a century was provided by $O$. Polunin (Charterhouse). He compared the 702 species recorded by J. D. Salmon for the Godalming district in 1849 with the 1,016 species known in 1955. During this period there has been a great decline in arable land and big increase in built-up areas, roads and paths. Alien plants form a larger proportion of the present flora, and a few species have become extinct during the period. Comparisons of this kind can make a valuable contribution to our knowledge of the changes which are taking place in the British flora generally.

Several exhibitors showed plants which are likely to prove of importance as additions to the list of British species. One of the most interesting of these is a Sparganium, noticed in substantial numbers this autumn along two to three miles of the banks of the Thames near Oxford; this was exhibited by $M$. D. Gwynne (Oxford). It has large fruits, of which a big proportion are two-seeded, and was at first thought to be a polyploid form of Sparganium ramosum $(2 n=30)$; but it has been found to have about the same chromosome number. Of species already described, it seems to be near the North American $S$. eurycarpum Engelm., but further study is required before it can be named. W. M. Baron and R. Kemp (Oxford) showed the grass Nardurus maritimus from recent collections in Berkshire, Oxfordshire and Hampshire and gave some of the previous records with maps showing the British and Continental distribution. From the time it was first noticed in Lincolnshire in $1903^{2}$, its status has been in dispute; but our increased knowledge of the species suggests that in calcareous grassland it may well be native. The inland Armeria exhibited by Miss E. J. Gibbons and J. E. Lousley was first recorded from near Grantham in $1726^{3}$, and there are many eighteenth-, nineteenth- and twentieth-century notices over a wide area of the old 'Lincoln Heath' in Lincolnshire and Leicestershire. In spite of the existence of supporting specimens, some botanists have regarded the inland occurrence of the usually maritime thrift as so improbable that the records have been dismissed as errors or introductions. In fact, there seems no real reason to doubt that the plants are native, and it was suggested that specimens gathered at Ancaster this year (and probably those at the other places) are A. elongata (Hoffm.) Koch, which occurs inland on sandy heaths over much of northern central Europe. The taxonomic rank of this plant is uncertain, and for the time being it should perhaps be treated as a variety of the 'Atlantic' A. maritima, which is a common coastal plant. An exhibit provided by the Department of Botany of the British Museum (Natural History) included specimens of plants of which accounts had appeared in Watsonia or the Proceedings of the Society during the past year.

One of the most interesting exhibits showing the important contribution which breeding experiments can make to taxonomic research was provided by M. Cole (Southampton). Chenopodium album and $C$. reticulatum are easily distinguished by the markings on their seed-coats, and they have been treated as separate species; but Mr. Cole has shown that the seed-coat markings on any particular plant are determined by the male pollen parent (xenia) and are therefore not a reliable guide to taxonomic status. J. P. Savidge (Liverpool) exhibited Callitriche platycarpa as a distinct species in Britain. His observations confirm recent work in the Netherlands ${ }^{4}$ that this is quite distinct from $C$. stagnalis in both chromosome and morphological characters. $\mathrm{H}_{\Theta}$ has noticed at least nine ecological forms, varying mainly in the form of the leaves, and the majority of old records and herbarium sheets of $C$. palustris (C. verna) and $C$. polymorpha in Britain can be referred to this species. J. A. Ratter (Liverpool) demonstrated morphological criteria in the Dryopteris spinulosa complex. He showed that epidermal and spore characters readily separate $D$. spinulosa and $D$. dilatata. N. M. Pritchard (Oxford) exhibited forms 
of Gentianella campestris in connexion with biometric analysis and cultural experiments being undertaken to ascertain if $G$. baltica is distinct from $G$. campestris, and if so, whether $G$. campestris forms a uniform group. Dr. E. F. Warburg (Oxford) showed forms of Sedum forsterianum and its allies which he has under cultivation, while B. N. Bowden (also of Oxford) illustrated the differences in the stomata between Sesleria coerulea and the British S. varia with a map showing doubtful as well as the accepted records of the latter in Britain. J. G. Packer (University College, Leicester) had a critical review of the criteria used for distinguishing the genus Sieglingia, in which he concluded that the relationship between Danthonia calycina and Sieglingia decumbens is one of species and not of genus. J. Rossiter (Oxford) showed specimens of Ranunculus acris and $R$. bulbosus which he had had in cultivation from Teesdale and Durham, and suggested that they included two ecotypes in each case. P. M. Benoit showed two forms of Spartina townsendii that he had found on mudflats near Barmouth Junction station, one of which had anthers only 5-7 mm. long, incompletely exserted, or exserted on short filaments, with small imperfect pollen grains and the styles small. This more slender plant is perhaps male-sterile, and was compared with a stouter form with anthers $8-11 \mathrm{~mm}$. long exserted on long filaments with the pollen fully formed. P. D. Sell (Cambridge) and Dr. C. West exhibited a series of critical Hieracia and suggested that a long list of names in current use are synonyms of a single species.

It has already been shown that two species have been confused as greater bindweed-the native Calystegia sepium and the introduced $C$. sylvestris ${ }^{5}$, which is more common in many districts. To these, an exhibit by Dr. S. M. Walters (Cambridge) and Prof. D. A. Webb (Trinity College, Dublin) added a third, the pink-flowered $C$. dahuricus Herbert apud Sims, which can be distinguished by the narrow leaf-shape and hairy winged petioles, and is widespread. G. Halliday (Cambridge) showed how another alien, Arenaria balearica, has been recorded from numerous widespread localities in Britain. As long ago as 1861 observations of this plant in Scotland aroused heated argument, and in 1908 it was remarked that it was "gradually making its way into our flora"?. To describe Hieracium spraguei as an 'endemic alien' would appear to be a contradiction in words, but, so far as our knowledge goes, this is a true statement of the position. Pugsley in $1948^{8}$ described the species as new to science based on a plant found by Dr. T. A. Sprague in Buckinghamshire near Chorley Wood in 1923 and 1925. Despite careful search by several botanists, it could not be refound until R. F. Turney, who showed it at the exhibition, sent to Kew specimens collected by Mrs. A. T. Peppercorn in 1951. They have now found it in five localities in Buckinghamshire and one in Hertford. shire, but although the species is undoubtedly an alien in Britain, its native country is still unknown.

Mrs. B. H. S. Russell exhibited herbarium specimens and a drawing of Dichondra repens, a plant widespread both in the tropics and some temperate countries, which she had found established on dunes near Hayle, Cornwall. Miss C. M. Goodman showed a most interesting series of alien grasses found in fields in Worcestershire where their seeds had been introduced in wool 'shoddy'.

From the library of the Department of Botany of the British Museum (Natural History) was an exhibit of original drawings for Sowerby's "English Botany" for comparison with the copper-plate engravings of the first edition and lithographs of the third. From the same library came manuscripts of Wolley-Dod's "Flora of Sussex", Rea's "Botany of Worcestershire" (with the published works for comparison), Benbow's "Floras of Uxbridge and District and of Middlesex", and Trimen's annotated copy of Brewer's "Flora of Surrey". Mrs. H. N. Clokie (Oxford) showed specimens and manuscripts throwing new light on Dillenius and John Sibthorp. It seems that the types for Dillenius's new species in the third edition of Ray's "Synopsis" are likely to be found among Sherard's specimens rather than in the Dillenian Herbarium, most of the material of which was evidently collected after publication of the "Synopsis",

Other exhibits included coloured photographs of some British plants by $K$. Le Sueur, an interesting photograph of Ophrys fuciflora believed to have been found in the Cotswolds, with an account of the circumstances by C. Thomas, records from the Lleyn Peninsula by Dr. A. P. Conolly, the stolon system of Glaux maritima by F. N. Hepper and Euphrasias in southern England by P. F. Yeo. J. E. Loustey

1 Walters, S. M., Nature, 173, 1079 (1954).

Woodruffe-Peacock, E. A., The Naturalist, 408 (1903).

Woodruffe-Peacock, E. A., The Naturalist, 177 (1898).

Schotsman, H. D., Acta Bot. Nérl., 3, 313 (1954).

S Lousley, J. E., Rep. Bot. Soc. and Exch. Club, 13, 265 (1948).

- Sim, J., et al., Phytologist, 5 (N.S.), 32, 46, 127 (1861).

- Gregory, E. S., Rep. Watson Bot. Exch. Club, 2, 135 (1908).

- Pugsley, H. W., J. Linn. Soc. (Bot.), 54, 328 (1948).

- Druce, G. C., and Vines, S. H., "The Dillenian Herbaria" (Oxford, 1907).

\section{INTERNATIONAL ANALOGY COMPUTATION MEETING}

$T$

HE Société Belge des Ingénieurs des Télécommunications ot d'Electronique organized last year a series of lectures and colloquia on the various aspects of analogy computation. These meetings, held on a local basis, aroused so much interest and seemed to lead to such fruitful discussions that the Society decided, in collaboration with the Société Belge des Electriciens and the Société Belge des Mécaniciens, to organize a larger international conference on this subject. This meeting was arranged for the period September 26-October 2 in Brussels, and was attended by four hundred scientists and engineers from seventeen countries. Apart from many Belgian participants, strong delegations went from the United States, France and Great Britain, and among the foreign guests were several scientists from the U.S.S.R. and from Poland. In conjunction with the scientific sessions, an exhibition of analogue computing equipment and of many interesting and novel applications was held.

The great number of papers submitted for reading (one hundred and one) made it necessary to conduct two parallel sessions, and several additional discussion meetings in smaller circles took place. To preserve the unity of the conference, the following invited survey papers were given before the whole audience on succeeding days, before splitting up for the specialist parallel sessions: "Les analyseurs différentiels électroniques", by M. F. H. Raymond; "Electrical network analysers", by Mr. E. L. Harder; "La móthode d'analogie rhéoélectrique, ses possibilités et 